\title{
AEndringer i det redaktionelle workflow - fra OJS 3.1 til OJS 3.2
}

Først, når man er nået frem til siden 'Produktion' (fig. 1), vil man se en egentlig ændring i workflowet fra OJS 3.1 til OJS 3.2. Mens man i OJS 3.1 skulle indsætte manuskriptets publiceringsversion via linket 'Tilføj publiceringsversion' i nederste felt (fig. 2), er dette nu flyttet til den del, der hedder 'Publikation' (fig 3). Denne side kan hentes frem enten ved at aktivere knappen 'Planlæg publicering' eller ved at klikke på fanebladet 'Publikation'. Mens layoutdelen i OJS 3.1 kunne udføres via siden 'Produktion', foregår det i OJS 3.2 under såvel 'Produktion' som under 'Publikation' ${ }^{*}$. En eventuel layoutredaktør får således nu adgang til både produktions- og publikationssiden. På publikationssiden er det under linket 'Publiceringsversioner' den færdigredigerede fil placeres.

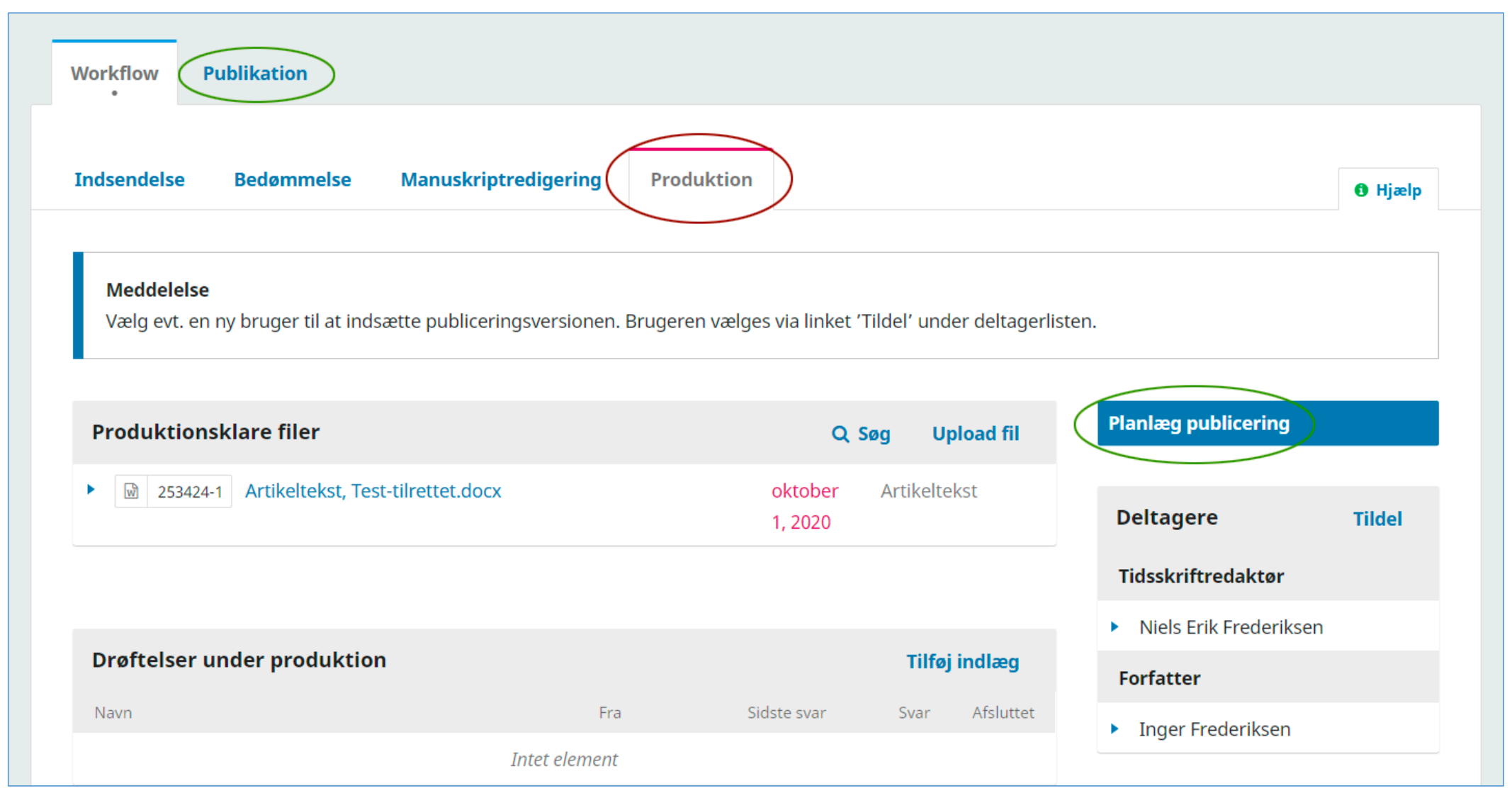


Det, der i OJS 3.1 var placeret på tre forskellige steder, nemlig A: på siden 'Produktion', B: i pop op-vinduet, der fremkom, når knappen 'Planlæg publicering' blev aktiveret, samt C: i pop op-vinduet under linket 'Metadata' (fig. 2), er nu blevet samlet under fanebladet 'Publikation' (fig 3).

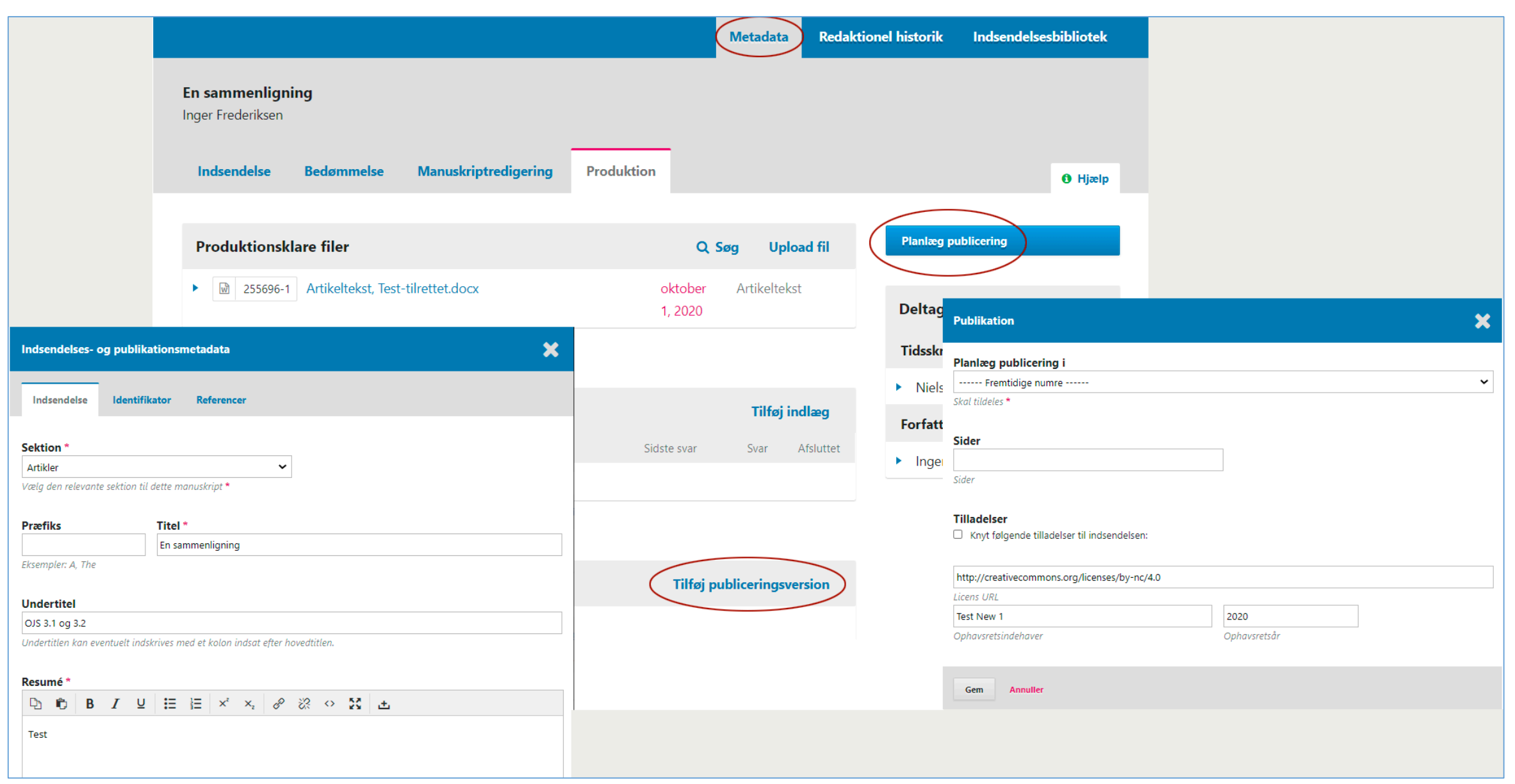

Figur 2 


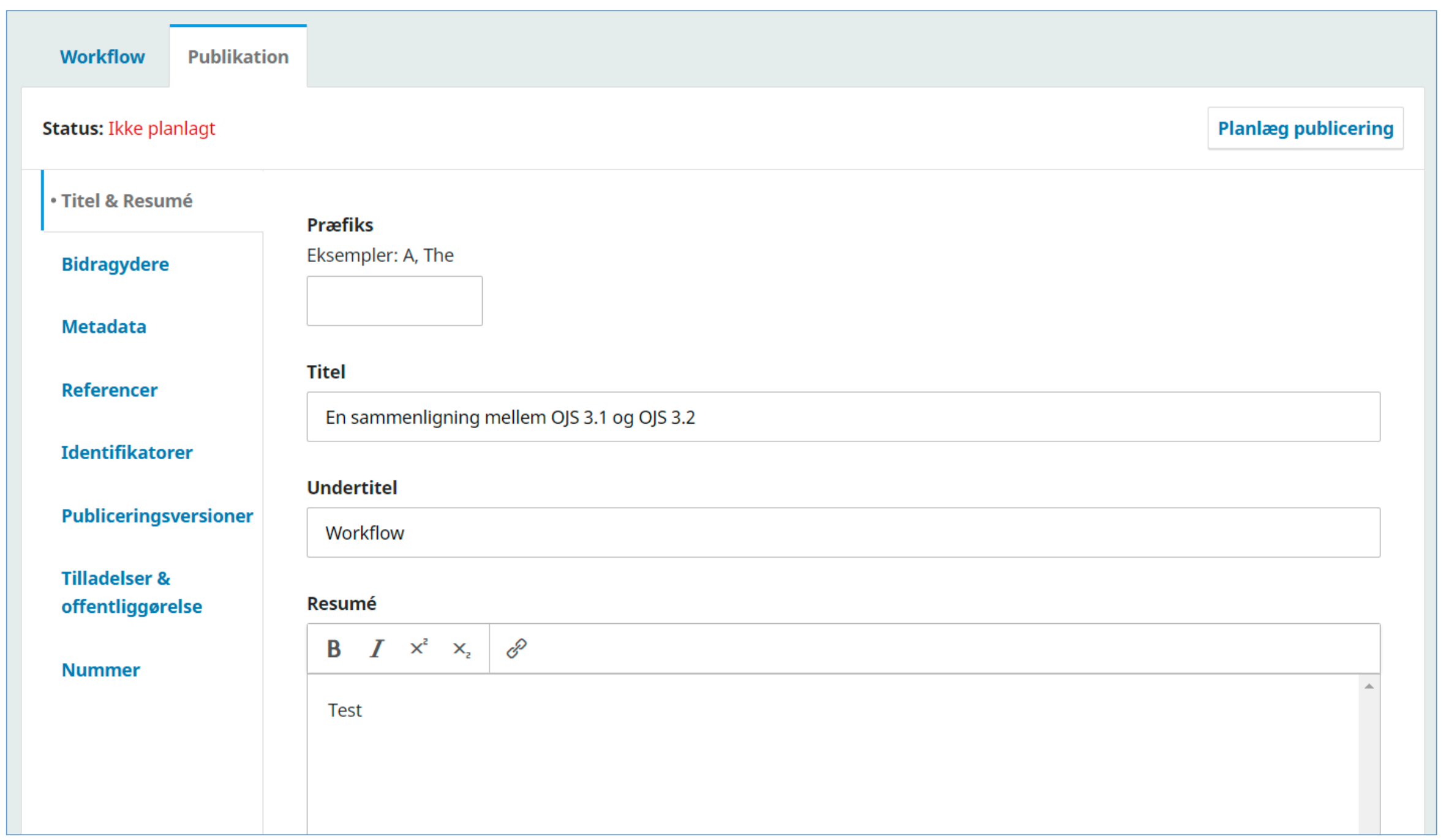

Figur 3

* Under 'Produktion' downloader layoutredaktøren den færdigredigerede Word-fil og omformaterer den til det $\emptyset$ nskede publiceringsformat (pdf, ePub, html, e.lign). Denne publiceringsversion indsættes derefter på siden 'Publikation' via linket 'Publiceringsversioner'. Layoutredaktøren har mulighed for at se sidernes indhold under de $\varnothing$ vrige links på publikationssiden, men har ikke skriverettigheder. 
Se eventuelt også PKP's egen guide: https://docs.pkp.sfu.ca/learning-ojs/en/production-publication 